\title{
ЕКСПРЕСИВНІСТЬ ІНШОМОВНОГО СЛОВА В СУЧАСНИХ УКРАЇНСЬКИХ ТРЕВЕЛОГАХ
}

У статті розглянуто експресивність іншомовних слів, зокрема екзотизмів, варваризмів і агнонімів у сучасних українських тревелогах. Актуальність дослідження обумовлена поглибленням глобалізаційних процесів $i$, як наслідок, взаємопроникненням культур. Метою роботи є виявлення основних функцій іншомовних слів у текстах тревелогів. Основним завданням є виявлення стратегій уведення в текст іншомовних слів. У результаті дослідження з'ясовано, що іншомовні елементи вносять у текст своєрідну експресію - і ту, щзо вже існувала в иих одинииях у мові-джерелі, і ту, якою іх наділяє автор у процесі лінгвістичного осмислення подорожніх вражень.

Ключові слова: екзотизм, варваризм, агнонім, стратегія, власна назва, концептуалізащія.

Moshtagh Ye. Expressiveness of Foreign Words in Modern Ukrainian Travelogues. The article discusses the expressiveness of foreign words, in particular exotisms, barbarism and agnonyms in modern Ukrainian travelogues. Travelling is a situation of intercultural contact when a person becomes acquainted with new expressive means of a foreign language. The brightest of them become part of the linguistic organization of the text. A significant part of such units conveys the specific expression of the unknown, unusual, exotic. The relevance of the study is due to the deepening globalization processes and, as a consequence, the interpenetration of cultures. The purpose of the work is to identify the main functions of foreign words in the texts of travelogues. The main objective is to identify the main strategies for introducing foreign words into the text. First of all, it concerns proper names, more often - geographical names, less often - personal names. Four strategies have been distinguished. The first strategy for introducing foreign words is to describe or indicate the connotations and associations that arise from the phonetic form of the word. The second strategy is to compare the expressive proper name with reality. Here complementary relationships are possible (the proper name conveys certain expectations, and the realities confirm and expand them). The third strategy is a language game with exotic proper names. It is quite natural that the most typical manifestation of such a game is the approach of a foreign language to one's own language, the humorous "Ukrainization". The fourth strategy is described as a conceptualization of borrowed proper names giving them important meaning on the basis of existing ones. An example of this is onym Branzolia, which became the name of the entire book of Maryna Hrymych and is gradually conceptualized in it. 
As a result of the study, it has been found out that foreign-language elements introduce a kind of expression into the text - both the one that already existed in these units in the source language, and the one given by the author in the process of linguistic comprehension of travel impressions.

Key words: exoticism, barbarism, agnonym, strategy, proper name, conceptualization.

\section{Вступ}

Завдяки інтенсифікації глобалізаційних процесів спостерігається взаємопроникнення різних культур. Подорож $є$ ситуацією міжкультурного контакту, коли відбувається знайомство людини з новими для неї виражальними засобами чужої мови. Найяскравіші з них стають частиною мовної організації тексту. Значна частина таких одиниць передає специфічну експресію невідомого, незвичного, екзотичного. Усе це зумовлює актуальність дослідження.

Експресивні засоби відіграють ключову роль у текстопородженні, пов'язаному із передачею подорожніх вражень. Надзвичайно цікавим феноменом $€$ введення в текст іншомовних одиниць, але їхня доречність і функціональна навантаженість потребує окремого вивчення. Метою роботи є виявлення основних функцій іншомовних слів в текстах тревелогів. Основне завдання - виявити основні стратегії введення в текст іншомовних слів. Означеній проблемі, зокрема побутовізму як лінгвокультуремі, присвячено праці С. П. Бибик (Бибик, 2008). Мовно-естетичним культурним знакам присвячена розвідка С. Я. Єрмоленко (Єрмоленко, 2009). Знаки української етнокультури досліджував В. В. Жайворонок (Жайворонок, 2006). У своїй роботі спираємось на праці Н. В. Самчелкіної (Самчелкина, 2013), присвячені мовному явищу агнонімії.

\section{Методи дослідження}

Методи дослідження визначаються метою й завданнями. Основним методом роботи є описовий, застосування якого дозволило систематизувати характеристики подорожей на стилістичному й дискурсивному рівнях. У процесі добору матеріалу для дослідження використовувався метод суцільної вибірки. Контекстний аналіз дав змогу вивчити лінгвальні й екстралінгвальні фактори, що впливають на посилення виразності значення, з урахуванням специфіки текстів подорожей. 


\section{Результати та дискусії}

3 метою вирішення основного завдання слід зазначити, що екзотична специфіка передусім стосується власних назв, частіше - топонімних, рідше - антропонімних. Щодо них ми виділяємо чотири стратегіï.

Першою стратегією введення їх у текст є опис або принаймні зазначення конотацій і асоціацій, що виникають у зв’язку з фонетичною формою слова, наприклад: «Італійська мова така ж милозвучна й співуча, як українська. Окремі ії власні назви своїм оригінальним ніжним звучанням огортають міста ореолом таємничості. От Генуя - італійською вимовляється Дженова - така ж солодко-зваблива, як торт "Смерекова хата" - ззовні ілюзорна хатинка, вкрита снігом сметанно-вершкової маси, а всередині - вишнева насолода. Щось таке» (Олендій, 2012: 23-24). Такі розгорнуті образи трапляються рідко, частіше у вислові констатується наявність певних емоцій, які викликає власна назва: «Тому вирішено було їхати [...] в замок, щзо здавна дражнив уяву самою своєю назвою - Перапертуза (я навмисно вживаю каталанську замість франиузької “Перепертюз")» (Карпа, 2014: 24).

Другою стратегією є зіставлення експресивної власної назви з дійсністю. Тут можливі відношення доповнення (власна назва передає певні очікування, а реалії ії підтверджують і розширюють): «Найбільше мене зачарували відениі - спокійні, доброзичливі, готові прийти надопомогу й пояснити, а то й намалювати на клаптику паперу, якдійти до Кунстісторішемузеум - Музею історії мистецтв. Господи, я по складах, ламаючи язика, вимовляла ию назву одного з найбагатших у Європі музеїв, а коли потрапила туди й побачила фантастичну колекиію, то раз у раз ловила себе на тому, що не вірю власним очам» (Воронина, 2010: 172); також відношення заперечення (очікування, асоційовані з фонетичною формою, не справджуються): «Тикнули ми тоді, пам'ятаю, пальцем у карту й опинилися в штаті Opicca. Звучить красиво, а по факту, крім храму Сония (Золотої Коліснииі) в Конарку та кількох інших індуїстських святинь, краси там небагато. Або ж ї̈ просто не видно під тоннами сміття, котре охочі місиеві рибалки й туристи з Калькутти залишають на березі. Те, щь на карті виглядало як пляж, виявилося по факту нетрищами, де відходи викидалися просто з вікон бідняцьких хатинок» (Карпа, 2014: 66). 
Третя стратегія - мовна гра з екзотичними власними назвами. Цілком природно, що найбільш типовим виявом такої гри стає наближення іншомовного слова до власної мови, жартівлива «українізація»: «В Едмонтоні, чи то пак - Едмонтонівиі (так ми із сином перейменували ие симпатичне й затишне провінційне місто)...» (Воронина, 2010: 81); «Арафат (або ж як ми нарекли його - Арафатко) сумлінно вчить украйнську мову...» (Яременко, 2016: 84). Інколи мовна гра пояснюється не лише бажанням «українізувати», а й складністю фонетичної форми для запам'ятовування й відтворення: «...до аеропорту в Трівандрумі, котрий ми, поки не вивчили його поважну офічійну назву Тіруванантапурам, називали по-гопницьки: “Трівадном"» (Карпа, 2014: 36). Зближення фонетики дозволяє засобами мовної гри передати й оцінку: «У Катманду в старому центрі міста, на Дурбар-сквері, досі оперують велорикші. Головно возять вони товстих дурбар-туристів» (Карпа, 2014: 93). Виникає оказіоналізм, який поєднує конотації комізму й новизни.

Четверту стратегію ми окреслюємо як концептуалізацію запозичених власних назв, наділення їх важливим змістом на основі вже наявного. Прикладом цього є онім Бранзолія, що став назвою всієї книжки Марини Гримич і концептуалізується в ній поступово. На початку авторка подає загальні фонетичні асоціації (перша стратегія): «Навіть у поєднанні звуків “брррааазззз” є щось заворожуюче. Галицькі селяни називали ї Бранзолія, іноді навіть Вобразилія» (Гримич, 2015: 5). Згодом авторка розгортає концептуалізацію, експліцитно розписуючи семи: «Пишучи про українсько-бразильське життя, я вживатиму [...] термін, створений самими переселениями, - Бранзолія. У ньому є все, щзо потрібно мені для того, щоб витягнути із загальнобразильської культури украӥнський “екстракт": архайчність, дитинну наївність, очікування дива, екзотичність і разом з тим “домашність", “рідність” (Гримич, 2015: 9). Далі авторка цитує прецедентний текст народної емігрантської пісні, у якій згадується це слово («Бранзолія - новая Австрія»), а загалом у тексті відбувається розрізнення слововживань: Бразилія - на позначення великої поліетнічної країни, Бранзолія - ії український складник.

Треба відзначити, що концептуалізація слів, почутих у Бразилії від тамтешніх українців, узагалі типова для тревелогу Марини Гримич. Це відбувається й із загальними назвами, що їх можна кваліфікувати як екзотизми. Наприклад, слово шімарон (chimarrão), яке позначає 
напій з місцевої рослини ерва мате. Опис реалії спочатку просто являє собою розповідь про рослину й спосіб заварювання чаю, але потім поступово в тексті розкривається культурний зміст напою, при цьому він наділяється культурними конотаціями, а назва, відповідно, - експресивністю: "Шімарон - це передусім спосіб спілкування, соціальний звичай, який поєднав у собі традицї гостинності та солідарності, дружби, довіри» (Гримич, 2015: 93); «Я вважаю шімарон соціокультурним символом сьогоднішніх украйниів Бразилії, та й узагалі - сільського населення иієї крайни, бо в цьому звичаї є довіра, є традищійність, є ритуалізованість» (Гримич, 2015: 99). У таких випадках можемо говорити про те, що побутовізми як конотовані елементи мовної тканини відображують національно-культурну реальність і стають лінгвокультуремами (Бибик, 2008: 32), мовно-естетичними знаками етнокультури (Єрмоленко, 2009; Жайворонок, 2006), причому й місцевої, бразильської португаломовної, і української.

Аналогічної концептуалізації зазнає фітонім піньор - назва дерева родини соснових Araucaria angustifolia. На початку слово подано як назву частини фауни регіону, де мешкають у Бразилії українці, і наведено його дескрипцію ( ЦЦе високе дерево з могутньою кореневою системою і крислатою пласкою голчастою кроною на верхівці» (Гримич, 2015: 11). Але згодом завдяки інтертекстуальності (цитатам із друкованих джерел і мовлення інформаторів) стає зрозумілим культурний зміст назви, дерево тісно пов'язується з життям української громади, з'являються його похідні (піньорчик - весільний аналог українського гільця (Гримич, 2015: 117), а в кінці твору встановлюється прямий зв'язок понять і символічний зміст слова: «...саме так я відчуваю дивовижне украӥнське життя під піньорами» (Гримич, 2015: 152).

У тревелозі Анни Яременко концептуалізується слово музунгу так місцеві африканці називають білих людей. Спочатку в тексті це слово виконує номінативну функцію й уживається в основному в контекстах, де йдеться про зовнішнє сприйняття самої авторки і іï подруги: «дві музунгу (цебто білі) та двоє маленьких африканців мовчки дивилися одне на одного» (Яременко, 2016: 9). Згодом із частотою вживання це слово набуває емоційно-оцінного забарвлення: «Не перестаємо дивуватися сусіднім дітлахам, які щоразу невтомно тиияють пальиями нам услід і вигукують оте ненависне “музунгу"» (Яременко, 2016: 60). Несподівано воно стає частиною словника й мовлення самої авторки: «Зрештою, ми дісталися величезного торгового иентру. 
Перше, щзо кинулося в очі, - велика кількість білих людей, які бродили тут, ніби в себе вдома. Інстинктивно хотілося тицьнути в них пальцем і прокричати: "Музунгу!". А що ви хочете? Ми щойно вибралися з хаш, де встигли трішки здичавіти...» (Яременко, 2016: 80). Динаміка сприйняття цього слова наочно показує зміни у свідомості й самосвідомості письменниці-мандрівниці.

Також подорож стає засобом закріплення конкретних асоціацій за вже відомими словами, які в індивідуальному лексиконі позначені експресією загадковості. Ми кваліфікуємо такі слова як агноніми (термін В. Морковкіна й А. Морковкіної - мовні одиниці, що незрозумілі або недостатньою мірою зрозумілі носієві мови (Самчелкина, 2013). Подорож стає моментом розширення розуміння слів, тобто вони втрачають агнонімний статус, і на цьому також може будуватися їхня підвищена виразність: «Керала ще сто років тому підманювала до себе мою увагу отими своїми таємничими backwaters. Що ие за такі “задні води", думала я, і чи є там море взагалі - а то все про беквотерз та про беквотерз путівники пишуть і фотки показують. Де-факто ж ми потрапили на цілком собі нормальний океан, і про таємничі беквотерз довелося випитувати хіба що в інших мандрівників - місцеві такого терміна не знали. Так от, беквотерз - то ціла мережа озер, лагун, каналів і річок. Мальовничих і не дуже, судноплавних і геть вузесеньких» (Карпа, 2014: 73). Зняття зі слова агнонімності в цьому разі $€$ мовним відображенням набуття нових знань.

У слів, які ми розглянули вище, первинною $є$ номінативна функція, і лише в авторській інтерпретації й у контексті вони набувають експресивності. У тревелогах ми виявили також мовні засоби, що зі стилістичного погляду $є$ варваризмами, при цьому в мові-джерелі вони вже мають експресивний характер. В українському тексті вже закладена в них експресивність посилюється іншомовністю. Наприклад: «Усередину товстого млиния заховано шинковану телятину, салат, помідори і все це приправлено гострим соусом - buоnissimissima - “предобре”, як каже Марчелло» (Олендій, 2012: 10). В італійській розмовній мові трапляються гіпертрофовані, афіксально редупліковані форми найвищого ступеня порівняння прикметників, що покликані підвищити ступінь експресії й оцінки. Аналогічне фінське слово наводить Ірен Роздобудько: «€ ще одне слівце, найнеобхідніше, якщо ви мандруєте иією крайною, - “херкуліста”. Увага: стає у пригоді кожні дві-три години. Вимовляється - з захватом. Означає - “уже смачно”. 
Діє - миттєво. Взагалі, все тут “херкуліста”» (Роздобудько, 2011: 15). Крім емоції захвату, зокрема від смачної їжі, іншомовні лексичні вкраплення супроводжують й описи інших емоцій: «Basta! (Достатньо!) Писатиму книгу! I текст про Лівіньйо буде однією з їі численних частинок» (Олендій, 2012: 86).

Грецьке вкраплення сега-сега виконує роль не інтенсифікатора, а, навпаки, деінтенсифікатора емоцій, стримує людину й теж набуває експресивносі саме в такий спосіб: «Тут ніхто нікуди не поспішає! А на будь-яку поквапливу інтонацію в голосі, якою часом грішать туристи, почуєш тагідне: “Сега-сега!” Це щось на кшталт - “тихіше, повільніше”. І ти розумієш, що, справді, куди поспішати? У метаборичному сенсі: чим довще готується їжа - тим гостріше очікування і бажаніший смак. А в режимі "сега" краще міркується "про вічне"... Отже, вечеряли ми дуже “сега"» (Роздобудько, 2011: 98).

Зрідка в тревелогах спостерігається протилежна ситуація, коли українські слова додатково екпресивізуються через використання представником іншої мовної спільноти: "Арабат (або ж як ми нарекли його - Арафатко) сумлінно вчить украӥнську мову, вміє казати слова "так”, “ні”, “метелики” й “хто тут шлангує?!” (Яременко, 2016: 84). Комізм контрасту вноситься неочікуваною семантикою й стилістикою останнього речення.

\section{Висновки}

Унаслідок дослідження було виявлено, що іншомовні елементи не лише вкраплюються в текст, а й уносять у нього своєрідну експресію - і ту, що вже існувала в цих одиницях у мові-джерелі, і ту, якою ï наділяє автор у процесі лінгвістичного осмислення подорожніх вражень. Прикметною для тревелогів вважаємо експресивність іншомовного слова (екзотизмів, варваризмів, агнонімів), котре вводиться в текст як репрезентант інакшої навколишньої дійсності в ході світопізнання. 3 огляду на це було виділено низку стратегій, що ними послуговуються автори: розкриття конотацій й асоціацій, що їх викликає певне слово, зіставлення їх із враженнями від дійсності, мовна гра, а також цілеспрямована концептуалізація мовної одиниці. Також варваризми переносять у текст експресію, якою вони наділені в мовіджерелі, і фрагменти картини світу, з якими вони там пов'язані. Той факт, що твори означеного жанру набувають усе більшої популярності, дає підстави вважати перспективним їхнє дослідження на лінгвістичному й дискурсивному рівнях. 


\section{ЛIТЕРАТУРА}

1. Бибик С. П. Побутовизм як лінгвокультурема. Наук. зап. Наu. ун-ту «Осmрозька академія». Сер.: Філологічна. 2008. Вип. 10. С. 31-35. 2. Воронина Л. У пошуках Oroпого. Київ: Нора-Друк, 2010. 176 с. 3. Гримич М. Бранзолія: Подорожні записки. Київ: Дуліби, 2015. 156 с. 4. Єрмоленко С. Я. Мовно-естетичні знаки української культури. Київ: Ін-т укр. мови НАНУ, 2009. 352 с. 5. Жайворонок В. В. Знаки української етнокультури: словник-довідник. Київ: Довіра, 2006. 703 с. 6. Карпа I. Baby travel. Подорожі з дітьми, або Як не стати куркою. Харків: Клуб сімейного дозвілля, 2014. 208 с. 7. Олендій Л. Mia Italia. Львів: АРC, 2012. 180 с. 8. Роздобудько I. Мандрівки без сенсу і моралі. Київ: Нора-друк, 2011. 192 с. 9. Самчелкина Н. В. Агнонимия как языковое явление. URL: http://ecsocman.hse.ru/data/2013/04/23/1251457447/Pages from CПО 1 2012-24. 10. Яременко А. Листи з екватора. Київ: Брайт Стар Паблішинг, 2016. 120 с.

\section{REFERENCES}

1. Bybyk, S. P. (2008). Pobutovyzm yak linhvokulturema [Householdism as a linguistic culture unit]. Nauk. zap. Nats. un-tu «Ostrozka akademiia». Ser.: Filolohichna - Scientific notes of the National University of Ostroh Academy. Series: Philological, 10, 31-35 [in Ukrainian]. 2. Voronyna, L. (2010). U poshukakh Ogopogo [In search of Ogopogo] . Kyiv: NoraDruk [in Ukrainian]. 3. Hrymych, M. (2015). Branzoliia: Podorozhni zapysky [Branzoliia: Travel notes]. Kyiv: Duliby [in Ukrainian]. 4. Yermolenko, S. Ya. (2009). Movno-estetychni znaky ukrainskoi kultury [Linguistic and aesthetic signs of Ukrainian culture]. Kyiv: In-t ukr. movy HAHU [in Ukrainian]. 5. Zhaivoronok, V. V. (2006). Znaky ukrainskoi etnokultury: slovnyk-dovidnyk [Signs of Ukrainian ethnoculture: dictionary directory]. Kyiv: Dovira [in Ukrainian]. 6. Karpa, I. (2014) Baby travel. Podorozhi z ditmy, abo Yak ne staty kurkoiu [Baby travel. Traveling with kids or How not to become a hen]. Kharkiv: Klub simeinoho dozvillia [in Ukrainian]. 7. Olendii, L. (2012). Mia Italia [My Italy]. Lviv: ARS [in Ukrainian]. 8. Rozdobudko, I. (2011). Mandrivky bez sensu i morali [Traveling without meaning and morality]. Kyiv: Nora-druk [in Ukrainian]. 9. Samchelkyna, N. V. (2013). Ahnonymyia kak yazukovoe yavlenye [Agnonymy as a language phenomenon]. Retrieved from http:// ecsocman.hse.ru/data/2013/04/23/1251457447/Pages from SPO 1 2012-24. [in Russian]. 10. Yaremenko, A. (2016). Lysty z ekvatora [Letters from the equator]. Kyiv: Brait Star Pablishynh [in Ukrainian].

Моштаг Євгенія Сергіївна - кандидат філологічних наук, доцент кафедри іноземних мов, Харківський національний університет міського господарства імені О. М. Бекетова; вул. Маршала Бажанова, 17, м. Харків, 61000, Україна.

Tel.: +38-050-549-08-39

E-mail: Evgeniamoshtagh@live.com

http://orcid.org/0000-0002-2174-8312

Moshtagh Yevheniia - Ph.D in Philology, Associate Professor, Department of Foreign languages, O. M. Beketov National University of Urban Economy in Kharkiv; Marshala Bazhanova Str. 17, Kharkiv, 61000, Ukraine.

Надійшла до редакції 16 лютого 2020 року 